\title{
Nominal Description of the Bukhara District
}

\author{
Nodira Adizova
}

\begin{abstract}
The thematic-nominal classification of Bukhara district toponymy is presented in this article. The names of some microtoponms include the names of the Turkic peoples, including the tribes and tribes of the Uzbek people, and their branches and networks, and we have analyzed and commented on them. It discusses topical issues of toponymics, including the etymology of microstructures of Bukhara district.
\end{abstract}

Keywords : Onomastics, toponyms, microtoponym, macrotoponym, footsteps, agronym, necron, lexical basis, etymology, linguistic, morphemic.

\section{INTRODUCTION}

$\mathrm{T}$ opics are objects of study of linguistics, geography, history, geology. They reflect the history and destiny of the people and the people. The place names are one of the unique monuments of nations, nations and peoples with a long history.

This is because they represent a world of history and destiny. As a separate branch of onomastics linguistics, famous etymological studies of toponyms and their vocabulary in toponymics, which is one of its branches, are of great theoretical and practical significance. Materials and methods of the article. For the article, more than 1,450 toponymy materials collected in the Bukhara district toponymy for the period 2017-2019 were collected as the analysis object.

Illustrative, historical and comparative scientific methods were used to cover the subject.

\section{LITERATURE REVIEW}

Although the article focuses on the linguistic-etymological and morphological studies of toponyms of Bukhara district, a general overview of the place names to date; both linguistic and geographical; historical and linguistic; descriptive and etymological considerations are worth exploring. The present study has paid close attention to various principles and methods of etymological analysis of toponyms, as well as issues related to research implementation. They were supported by evidence in the case of the etymological analysis of toponyms.

Therefore, the etymological analysis of one or more toponyms when referring to a method, factor or principle is given as an example. However, we do not deny that other principles, methods, and factors may apply to that topology

Revised Manuscript Received on October 15, 2019.

* Correspondence Author

Nodira Adizova *, PhD student at Bukhara State University that is etymologically analyzed. In the etymological study of toponyms, linguistic orientation along with geographical and historical directions is an important aspect of onomastic research.

As a prerequisite for studying the etymological study of toponyms and their etymological study for logical disclosure of this edge in a logical manner, the following were identified: Approaches to the etymological study of toponyms and their vocabulary bases; Factors providing etymological study of toponym and their dictionary bases: principles and methods of etymological study of toponym and their dictionary; etymological study of toponyms. The opening of each chapter focuses on the study of these issues to be covered.

\section{RESEARCH METHODOLOGY}

The principles, methods, factors, and motivations that are presented as an etymological study of toponyms and their vocabulary bases differ substantially from those of other disciplines. Each subject or area has its own characteristics of onomastics, including toponymics, as they are the object of study, the subject, the conceptual base. The direct application of the principles, methods, factors, and motivations of a particular subject to another subject is not justified. Depending on the requirements of the area under study, they should be added to something or taken away from them.

It should be noted that the principles and methods that are the theoretical basis of the lexicon and etymological studies of toponyms mentioned in the work, as well as the issues discussed in this study, are not a closed system for onomastic, toponymic research. Instead of listing the existing methods and principles in science, it is better to focus on the toponyms that have been collected, and to focus on the related issues, factors, principles and methods within our research topic. The issues presented are theoretical and practical implications for the etymological study of toponyms.

\section{DISCUSSION}

Our research focuses on the factors, principles, and methods, as well as how to address the problem of their application, as a way to conduct a general survey of Bukhara district topologies. The research carried out in a comprehensive theoretical and practical justification of the object of our research is, in a sense, both scientific and practical. This work is one of the first scientific studies on the method of monographing of the toponyms of Bukhara 


\section{Nominal Description of the Bukhara District}

district.

Practical and theoretical studies, beginning with the classification and characterization of toponyms, show that there is a need for a theoretical solution in the field of onomastics, including toponymics, to conduct an exhaustive etymological analysis and research. Investigating the toponymy of a particular area begins with the collection of toponymic material in that area.

This requirement results in the classification of onomastic material based on certain principles and methods. Therefore, researchers described the classification of place names as one of the main problems: "The description and analysis of known horses is incomplete without classification. The classification is directly involved in the work of the author, or in some studies it may be the author's primary purpose, and the type of material expressed in the classification material is based on the criteria. "[10,55] Almost all historians are involved in the description of the onomastic material.

The success of the research depends on the correct classification of the material. In the course of our research, it was revealed that the following toponyms of Bukhara district are available.

Famous geographical and artificial objects on land. These are divided into the following groups.

1.1.1. Footnotes. These include village, aul, and makhallya.

The name of the village and auls is an integral part of the oykimony and constitutes the main part of the Bukhara district toponymy.

Most of the village names in the Bukhara district are ancient, historic names, and the reasons for their naming are often forgotten. So, the names of villages such as Yurinpoyon, Patput, Leilak, Tutikhushk, Janafar, Chappa, Jonbobo, Mijona, Otquchi, Obitoratkabi.

The following is a brief overview of some of the village names.

Arabhona is the name of the district in the district. The name of the village and neighborhood that is found in most regions of Uzbekistan. The Arabic, Arabian, Arabo (Arabic) and other similar terms are also used and have the meanings of "Arabian Village", "Arab Residence".

The Arabs of Central Asia, from the time of the Arab conquest, have been associated with the Arabs of the later centuries. There are also villages, mahallas and guzars in Bukhara, Vobkent, Jondor, Kagan, Romitan, Peshko, Alat, Shofirkon, Karakul and Gijduvan districts. Prof. In his research T. Nafasov noted that there are the following types of Arabs in Arab settlements:

1) Arabs who do not speak Arabic and speak the dialect of blackness;

2) Arabs who speak Arabic, speak Uzbek and do not know Tajik;

3) Arabs who do not speak Arabic and Tajik, but speak Uzbek;

4) Arabs who do not know Arabic and speak Tajik and Uzbek.

The last two types of Arab settlements are called Arabian.
Ethnic content is the basis for naming places [6, 45].

Name of place in Bukhara district. Bukhara is a city with ancient history and rich in monuments. Narshakhi says that Bukhara has the names of Numijkat, Bumiskat, Madinat us-Sufria, that is, "Copper City", Madinah is a herbivor, or "City of Merchants." None of the cities of Khurasan has so many names. In one hadith Bukhara was called Foxira. On the Day of Judgment, the city of Bukhara boasts a large number of martyrs. There is also the story of Bukhara Bukhara. There is an idea that Bukhara is derived from the Sanskrit word "Vihara" and means "temple." According to archaeological evidence, Bukhara was founded in the middle of the first millennium $\mathrm{BC}$, and its name was found in early medieval Chinese sources (An, Ansi, Ango, Boko, Buku, Buku, Bukher, Bukhaer, Buhala, Bukhuala, Fuxo, Puxuala, etc.).

Three of these terms are Bukhara's Chinese names, and the rest is the Chinese pronunciation of the word "Bukhara"), which is thought to mean" the glory of God"[12, 282].

According to V.A.Lewis, the word Vihara is in the form of the word "parchar". According to Hafiz Tanish, the word "Bukhara" is derived from the word "Bukhara" and means "space of knowledge" in the language of firefighters. This pronunciation is close to the language of the Uighur and Chinese pagans, because they call the shrines "steam". The name of Bukhara is actually Lumijkat [17].

The Bukhara top is not alone. In the XI-XII centuries around the city of Balkh were the gates of Navbehor. Navbehar is not a "early spring" but a "new temple."

The etymology of the city of Bukhara is the etymology of the state of Bihar in India [7]. V.V. Shostakovich mentions the river Bukhara in Siberia. Near Bukhara was a village called Wul Bukhara (Jul Bukhara). One of the Bukhara provinces was called Bukharhitvar (Najar-kh danger) (Bukhara governors were called "bukharhudot"). There are neighborhoods, places. So, there are a number of toponyms in the Bukhara component.

Ancient Turkic runic inscription (in the cult dedicated to Kultegin) is known as Vuharak. It was Bukhara, but it was Bukhara. S.I. Malov commented on this place as Bukhara. Academician B.Y. Vladimirsev says that the name of the Sogdian is also mentioned in the monument, and Bukhara is really the word Bukhara troops. "

Some researchers believe that the word Bukhara may have been Eftalit, not Sanskrit. At the same time, they provide proof that the original letter of Bukhara is written with the letter " $\mathrm{p}$ " in the pseudo-written document [5, 150-163].

Bogikalon is the name of the district in the district. The toponym consists of two parts: garden (i) + kalon. The garden is a Persian-Tajik word with an area of fruit trees, vine and flowers; the orchard and the outside fortress and the orchard and vineyard have the meanings $[14,141]$. The word is also Persian and is large in size. mature; official; is used in terms of function or title superior [11, 582-583]. The "i" in the toponym is a Persian inscription. Garden $+\mathrm{i}+$ large 
is a large garden. The village is named after a large orchard in the area.

Beshbori is the name of the district in the district. Toponym is a common Turkish word and is rich + brown. The ancient meaning of the rich word is "great", "great", "great", "high volume"; "Holy", "sacred"; Are regarded as the "big owners" and the "wealthy". In the ancient Turkic peoples, the word "rich" may have changed, the simplified form of the word Umai (goddess, goddess, legendary goddess, goddess of the child, goddess of creation) According to T.Nafasov. The wolf is a totem and cult creature in ancient Turkic nations. Ancient Turkic ashin tribes were thought to have descended from them. Boy is a great, strong wolf. There is a rich seed of bells and whistles. Boyboy is the person's name. The name also comes from the totem and the seed. The village name is derived from the seed name $[6,65]$.

Generally, the Turkic tribes have the common names of the five kinds, namely, five, five, five, five, five, five.

The Great Silk Road is the name of a village in the district. An intercontinental caravan route that connects East and West in ancient and medieval times (2nd century BC 15 th century AD). The term Silk Road relates to Chinese silk, a valuable commodity transported on this road. Western countries have long been unaware of the mysteries of silk. The Great Silk Road was never used in the past.

The scientific study of the historical, geographical and cultural aspects of the Great Silk Road began in the second half of the 19th century by many scholars. Scientists from Western Europe, Russia and Japan have made significant contributions to the study. In particular, the Great Silk Road Encyclopedia was published in Japan. In 1877, the famous German scientist Karl Richtgofen in his major scientific work "China" called the system of roads linking different parts of the great Eurasian continent, the "Silk Road", later adopted the term "Great Silk Road". [12, 319-320]. The name of the Great Silk Road is laid on the main roads Tashkent - Bukhara, Tashkent - Termez, Tashkent Ashgabat.

Name of the settlement in Wahmkor district. Changed form of the word "waqf". According to S.Karayev, the word "waqf" is Arabic and means "bequeathed", "favored", "dedicated". In the Middle Ages and beyond, large lands, shops, craft shops, mills baths, objujoz and other properties were given to mosques, madrassas, hospitals and hospitals. to the needs of these institutions. The foundation documents play an important role in the study of toponymy of the Republic. In such documents, the boundaries of the foundations are clearly defined, and the neighboring villages and canals are listed.

There are toponyms in Uzbekistan, particularly in the Zarafshan Valley, such as Burkut Waqf, Waqf, Waqbi Gijbak, Waqf Qurghan, Old Waqf, Wahim, Vakhim, Vakim; The name of the Vakhmchorsi mahalla in Kokand also comes from the word "foundation" [17, 177-178]. The word wahm is associated with the word wafers in the sense of the word used here. The founder later became the Wahhabi. The name of the village in the VAG'OSKENT district. The toponym consists of two words - warp and kent. The first part of the topology is the word "barg", which means "water", "dam", "busy". In the Yaghnob language, which is also known as the new sugars, varg means "the top of the field" [6, 77]. The term Kent is used in both urban and rural areas. That is why many settlements in Turkestan ended in the tenth century.

Name of settlement in Dodxoh district. Dodhoh is a Persian word, meaning "demanding justice" and "wanting justice" [14, 231]. The word Dodhoh is the name of the post in the Kokand Khanate and the Bukhara Emirate: the chief of the castle, the leader; the supervisor of the boiler house is used in the sense of the raisicone. In the Kokand Khanate, this position was ninth in the list of officials (before the twist). In the Bukhara Emirate, the plaintiff's complaint was addressed to the emir and the name was applied to the complainant. In the Kokand Khanate, such an official was called a Huduya [13, 337-338]. Ownership or residence of such officials is named after this post. This is where the toponym came from.

Name of the settlement in Denov district. The word "deh", which is found in almost all the regions of Uzbekistan, originates from the ancient Persian "genius" - country, region, country, and deh, de, de, de dev. Denav, Dehcha, Dihiosio, Debalo, Decmaron, Debolo, Decha and others. So deh is a village and a nav is a new village, that is, a new village. Newer (more recently, later) rural settlements mean more villages. Denav's novel belongs to the time when he was named, at the time of his establishment. It is now a historical toponym [1]. The town next to it is named after the village, as it was built in recent times $[6,90]$.

House - Name of the district in the district. The topon consists of two parts: yobu + room. Yobu (Uzbek) is an Uzbek seed. The Yushu Kazakhs also lived in the Karshi steppe in the middle and lower reaches of the Zarafshan (Paiarik, Pastdargom, Kattakurgan, Narpay, Gijduvan), which were also scattered. He is engaged in animal husbandry and agriculture. Generations of Yobu are included in the Uzbek people [13, 462]. The village is named after the inhabitants of the Jaguar. Yobu is a Turkic ethnonym, a name of one of the Uzbek tribes. Sources can be found in the form of yobu, yovu, yawi, jaubi, jobu. About the position of Sugoblak in the following puppets of Ubaydullahan pen:

Sug'd ichida ulturarlar yobular,

Yobularning mingan oti yobilar.

Yobularning ilkidin el tinmadi,

Yobular tursin bu elda, yo bular.

One of the titles of Turkish supremacy was called yobgu (yabbgu). In the Orkhon-Yenisei monuments, the term "wild" is also found. In ancient Turks this title was given to the chief of the tribe or the head of the tribal alliance. The old khans of Central Asia were also called bad. The Yobulars constituted a small group of Uzbeks (about 4,000 as of 1926).

Rural names associated with yobu are most common in Samarkand, Bukhara and other regions. These include villages such as Eshmatjobi in Pakhtachi district, Yobukhona in Bukhara district, and Yobiarik in Konimeh district 


\section{Nominal Description of the Bukhara District}

[2, 57-58].

Name of settlement in Kobdin District. The full name of the village of Kobdin was formerly called "Khoja Kone Religion". Because of the fact that the majority of the population was farms, the village was named after Khodja Konidin at that time. Later, due to the population growth, small villages appeared on the hill and there was no need to live on the hill. The village called Khoja Konidin was scattered. Over time, the population reunited and the village of Khoja Konidin was renamed, and the word Khoja was not used, and it was called Kobdin, not religion.

The word Kobdin also refers to the villages surrounding the hill. For example, the north is called Upper Kobdin, the south is Lower Kobdin, and the east is called Farakti Kobdin.

Name of the settlement in Losha district. Could not determine the original orphan's toponym. In the past, there was a ruined, abandoned lake along the road from Bukhara to the medieval Mausoleum, and a village was built in the arid river. There is a view that the puzzle means "devastated", "afto". The 18th-century poet Turdi Faroghi used the word losha and wrote the following byte:

Molu dunyoni yig'ib, bir losha tang'a zulm edib,

Yuk og'ir, eshak yag'ir, manzil uzoqu yo'l xatar.

As it is known, the village of Losha on the road from Bukhara to the middle road has been destroyed and its name was given to it. Name of the settlement in Sangsabz Sang "stone", carrots - "green", "green"; The word "green" means "orchard." The meaning of my topony may be interpreted as "green stone" or "rock-garden-rock". Name of settlement in Usta Charmgar. The toponym comes from the words "top" and "charm". Master - a "qualified professional", "a vocational or vocational trainer"; mentor, master, master, "skillful at doing something; skillful "," comes from a famous horse, indicating that a person is a professional. "[15, 282]. Leather means "leather - thick skin, thick skin, old man [15, 357]." The name Charmgar used to refer to a village, neighborhood, guzar, street or shopping center where these occupants lived or worked.

According to legend, there is a large hill (now a cemetery) on the side of the village of Master Charmgar. The hill is surrounded by oaks, cotton fields and reeds, where the people graze their livestock. In the village at that time there were two or three courtyard masters living in the hillside, where they would ditch the hillside, put cattle and goat skins in about 30 large boilers, cover with wet hay in the lid and avoid steam. they boiled their pots. A week later, the boilers opened and the woolen skins were removed and processed, and the finished leather was sold to the Buccaneers. Hence the name of the village was called Master Charmgar.

1.1.2. Names of neighborhoods. The following neighborhoods are located in Bukhara district: Arababad, Loblozor, Past mahalla, Rost mahalla, Chandirabot, Archazor mahalla and others.

1.1.3. Name of roads, streets. This group of famous horses is called noodles, dronimons in the nomenclature. Most of the road names in Bukhara district are ancient. The following road names are found in the district. Afghanistan
Road, Kattamazor Road, Loblozor Road, Kayrakkash Road Kharos Road, Ray Dabiyon and many more.

1.1.4. Agronymes. The fields, plots, fields, fields and hills also have their own horses, which are called agronomies (Greek, agro-field, plowed land, cultivated fields). [9,27]

N.Okhunov as a scientist who studied agronomists in Uzbekistan. [8] Latipovs [4] are particularly noteworthy. There are about 450 agronomists in the Bukhara district. Here are some examples: Lands - Land of Alafpoya, Land of Baratak, Botiriy land, Bibidur land, Gatti's land, Dung land, Laylakuya's land, Kilmak land, Sangzor land and more. Peaks - Badasia Peak, Bibi Makhsumai Peak, Bibikhonim Peak, Devon Peak, Durman Peak, Hazratibibi Peak, Hazrat Ebb Hit, Kangav Peak, Koruk Peak, Saron Peak, Shanbi Peak and more.

\section{RESULT}

A. The classification of microstructures of the Bukhara district into thematic groups, with examples of almost all groups of toponyms in the area.

B. The names that are typical for the toponymy of the district are sculptures, agronymes.

C. Some types of microtoponim are not characteristic for toponymy of Bukhara district.

D. Most of the Bukhara microtoponim and necrotoponim are toponyms given to the famous horse.

\section{CONCLUSION RESULT AND}

Linguistic analysis of the toponymy of the territory of the Bukhara district of the Bukhara region allowed to reach the following general conclusions:

1. Ancient names of Bukhara district toponyms fund. These names are Uzbek (Turkic) and belongs to the Persian-Tajik language.

2. Spiritually-thematic materials of toponymy of the district Almost all types of toponyms in the area are classified.

3.However, the onomastic units that play the most characteristic and significant role for this region are the mammals, dromonimons, agroonimons and necronymes.

4.Observations have shown that Bukhara district toponymy is characteristic of making new names from well-known nouns and based on this anthropotoponim, ethnotoponim, topotoponim, the most productive are anthropotoponim and ethnotoponim.

5. The emergence and development of the toponymy of Bukhara district is related to the ethnic history of the long-lived history, social, political, economic and cultural life of the population living in the area, and not only for the linguistic field, but also for history, geography, ethnography, culture. and valuable material for the history of spirituality.

\section{REFERENCES}

1. Aslonov A.S. Linguistic analysis of microflora of Shofirkon district: Philol. name ... diss. $-\mathrm{T} .: 2005-187 \mathrm{~b}$ 
2. 2. Begaliev N. From the history of Uzbek ethnos. Samarkand, SamSCHTI Publication, 2005 57-58 p.

3. 3. Begmatov E., Aripov U. About the concept of microtoponim // Uzbek language and literature.-2000.-№3.-B, 25-28

4. 4. Latipov D. Toponimiya goroda Margilana i ego okrestnosteye: Autoref. dis. ... Candy. filol. Nauk. -T-1975.

5. 5. Livshist V.A., Kaufman V., Dyakonov I.M.The history of health of the Bukhara // History of the Vestnik drevney. No. 1, 1954, c. 150-163.

6. 6. Nafasov T. Kashkadarya village. - T .: "Editor," 2009, 430 p. 7. Nikonov VA In the toponimiku. - M .: Nauka, 1965. - 179 p.

7. 8. Oxunov N. Toponomy of Kokand Group District: Autoref.dis. ... Candy. filol. Nauk. -T-1978.

8. 9. Подольская Н.В.Словарь русской ономастической терминологии.-С. 27

9. 10. Superanskaya A.V. Общая теория собственных имен. - M.: Nauka. 1970. - S.55.

10. 11. The Language of the Interpretation of the Literary (Less than 2 Years). Dushanbe - 2008, 950 p.

11. 12. National Encyclopedia of Uzbekistan. Volume 12, Volume 2 - T . State Scientific Publishing House "National Encyclopedia of Uzbekistan". 2001, $-700 \mathrm{p}$.

12. 13. National Encyclopedia of Uzbekistan. Volume 12, Volume 3. -T State Scientific Publishing House "National Encyclopedia of Uzbekistan". 2002, -703 b.

13. 14. Explanatory Dictionary of the Uzbek Language. Volume 2, Volume 1 -M .: "Russian Language," 1981, 631 p.

14. 15. Explanatory Dictionary of the Uzbek Language. Volume 2, Volume 2 -M .: "Russian Language," 1981, 715 p.

15. 23. Karaev S. Toponymics. -T.: "National Society of Philosophers of Uzbekistan", 2006, 318 p.

16. 24. Hafiz Tanish Bukhari. Abdullanoma, Volume 1. - T.: 1966, 273 p. 